\title{
Judge's View Of Negligence Criminal Acts Which Cause Death In Traffic Scope
}

\section{Heri Joko Purnomo*) and Gunarto**)}

*) Student of Masters (S2) of Law Faculty of Law Unissula and Member of National Police at the Jepara Resort Police, email: muhnizam1975@gmail.com

$\left.{ }^{* *}\right)$ Faculty of Law Universitas Islam Sultan Agung

\begin{abstract}
The purpose of this research isto study, know and analyze the judge's point of view in the verdict of a case of negligence that causes the death of another person within the scope of traffic. In this study, the authors used sociological juridical methods with descriptive research specifications. The data used for this research are primary and secondary data. Based on the research, it was concluded that in positive law, the Defendant RK in case Number 186 / Pid.Sus / 2018 / PN.Jpa positively violated the provisions in accordance with the aggravating matter, namely the Accused's negligence caused the death of another person and also the Defendant did not have standardization driving license in the form of a driving license (SIM). Keywords:Judge; View; Negligence, Death; Traffic.
\end{abstract}

\section{Introduction}

In the division of conventional law, criminal law is included in the field of public law. This means that criminal law regulates the relationship between citizens and the state and emphasizes the public interest or public interest. Historically, the existing legal relationship was originally a personal relationship or private relationship, but in the course of time there were things that were taken over by groups or tribes and finally after the establishment of the State it was taken by the state and made into the public interest. Clear evidence can be seen in the Criminal Code Article 344 whoever seizes the life of another person at the request of that person, clearly stated with sincerity, is punishable by a maximum imprisonment of twelve years. ${ }^{1}$

The existence of Indonesia as a constitutional state is expressly stated in the explanation of the 1945 Constitution of the Republic of Indonesia (hereinafter abbreviated to the 1945 NRI Constitution) after the amendment, namely Article 1 paragraph (3); "Indonesia is a country based on law (rechtsstaat)".2 The indication that Indonesia adheres to the concept of a welfare state lies in the government's obligation to realize the state's goals, as contained in the fourth paragraph of the Preamble of the 1945 Constitution of the Republic of Indonesia, namely: "Protecting the entire Indonesian nation and all Indonesian bloodshed, advancing public welfare, educating the nation's life, and carry out world order".

\footnotetext{
${ }^{1}$ Kumpulan Kitab Undang-Undang Hukum, 2008, KUH Perdata, KUHP dan KUHAP, Wipres,p. 507.

${ }^{2}$ Anton Susanto, Ira Alia Maerani, and Maryanto, Legal Enforcement by the Police against Child of Criminal Doer of a Traffic Accident Who Caused Death (Case Study in Traffic Accident of Police Traffic Unit of Cirebon City Police Juridiction), Jurnal Daulat Hukum, Vol.3 No.1, March 2020, url: http://jurnal.unissula.ac.id/index.php/RH/article/view/8402/3928
} 
Basically, law has a very important role in social life, because law is not only a parameter for justice, order, tranquility and order, but also to ensure legal certainty. ${ }^{3}$ At the next level, law is increasingly directed as a means of progress and social welfare. ${ }^{4}$ Traffic crime cases generally occur accidentally, here there is only an element of neglect or negligence. Imposition of punishment to a person who because he neglects to commit a crime is called strict liability, meaning that there is a crime in which the defendant's mental state does not know and does not mean to commit an act. But even so, he is still considered responsible for the occurrence of the forbidden case, even though he did not intend to commit an act which turned out to be a crime. ${ }^{5}$

Basically, a traffic case is a type of violation case. Traffic violations are not regulated in the Criminal Code, but some are related to offenses mentioned in the Criminal Code, for example as regulated in Article 359 of the Criminal Code, namely because their negligence causes the death of another person and as regulated in Article 360 of the Criminal Code that is, because his negligence caused others serious injuries.

It cannot be denied that the rate of traffic accidents every year increases with the number of victims not small due to negligence or negligence which results in losses for others. Traffic criminal cases constitute an idea of amendment from the provisions of Article 359 of the Criminal Code, namely that whoever due to his / her mistake (negligence) causes another person to die, is punishable by a maximum imprisonment of five years or a maximum imprisonment of one year, the criminal threat in Article 310 paragraph (4) Act No. 22 of 2009 concerning Road Traffic and Transportation with a criminal penalty for six years and a maximum fine of IDR 12,000,000.00 (twelve million rupiah).

\section{Research Methods}

To conduct a study in this study the author uses the sociological juridical method to study and discuss the problems raised. This research uses this type of research with a descriptive method. The data used for this research are primary and secondary data. Primary data is data obtained directly from the field or from the first source and has not been processed by other parties. Then secondary data is data obtained from library research consisting of primary legal materials, secondary legal materials and tertiary legal materials. ${ }^{6}$

\footnotetext{
${ }^{3}$ Farhan Munirus Su'aidi, dan Abdullah Arief Cholil, Law Protection on Wife Whose The Claims Fall Due To Husband Refuse His Recompensation On Implementing Of Divorce Pledge, Jurnal Daulat Hukum, Vol.2 No.4, December 2019, url; http://jurnal.unissula.ac.id/index.php/RH/article/view/8367/3897

${ }^{4}$ Andi Hamzah, 2001, Bunga Rampai Hukum Pidana dan Acara Pidana, Ghalia Indonesia Jakarta, p. 14.

${ }^{5}$ Hengki Irawan, Sri Endah Wahyuningsih, dan Jawade Hafiz, Legal Protection For Victims Of Traffic Violations That Lead To Death (Case Study On Police Traffic of Rembang), Jurnal Daulat hukum, Vol.2 No.4, December 2019, url: http://jurnal.unissula.ac.id/index.php/RH/article/view/8349/3869

${ }^{6}$ Bambang Sunggono, 2010, Metodologi Penelitian Hukum, Rajawali Pers, Jakarta, p. 38.
} 


\section{Results And Discussion}

There needs to be strict action against the negligence of people who cause the death of others, especially vehicle drivers, who due to their negligence or lack of respect for the value of the souls of fellow human beings, causing traffic accidents in the form of collisions, falling vehicles in ravines or rivers, or overturning of vehicles due to Too many cargo in the form of goods or because of hopelessness or fire due to lack of care or research before driving a vehicle, all of which resulted in casualties, as regulated in Article 310 paragraph (4) of Act No. 22 of 2009.

But on the other hand, the manifestation of a justice needs to be upheld in every judge's decision in deciding a criminal case, especially a criminal negligence. Here the mental attitude of the person who gives rise to the forbidden condition is not against the prohibitions, he does not want or approve of the occurrence of forbidden things, but his fault, his inner self-righteousness when he does something that causes things to be forbidden is that he doesn't heed the prohibition. The position of the perpetrator in the interests of the criminalized needs to be considered by the judge in a fair consideration for the perpetrator with the judicial power of a judge for his consideration to see the legal literature from the positivistic, the judge's reasoning, as well as jurisprudence in looking at the source of one's negligence in driving which causes the death of other people of all sizes, including negligence which is very fatal or from other factors which are not purely due to the perpetrator's negligence but natural factors or factors of negligence from the victim who made the victim die, seeing the scope traffic is very complex as the object of a vehicle flow where one vehicle meets another and other objects that do not move in the area of traffic flow that affect motorists which become a complex factor in the incidence of accidents. This also requires a sharp analysis knife from a judge in considering his verdict on a criminal act of negligence that causes the death of other people in the scope of traffic.

Legal regulations governing road traffic accidents can cause material loss, and some even die in addition to serious and minor injuries and / or lifelong disabilities. Regulations regarding traffic accidents can be seen from several regulations concerning traffic itself and some of the applications contained in the criminal law book. Sometimes a result of a crime is so serious that it harms one's interests, such as the death of a human, so that it is felt unfair, especially by the victim's heirs, that the perpetrator who carelessly causes someone else to die, is left alone. In practice it appears, if a motorized vehicle driver hits a person causing the victim to die, ${ }^{7}$

In the author's research in the research study area, namely the Jepara District Court, the authors analyzed one of the decisions in the Jepara District Court relating to the verdict in the case of negligence which caused the death of

${ }^{7}$ Jamal Abdullah, Kepastian Hukum Terhadap Pelaku Tindak Pidana Delik Biasa yang diselesaikan dengan Mediasi (Studi Kasus Kecelakaan Lalu Lintas yang Menyebabkan Kematian), Jurnal Hukum, Vol.III No.1, February 2016, p. 8 
other people in the scope of traffic in case Number 186 / Pid.Sus / 2018 /PN.Jpa as follows:

Criminal decision No.186 / Pid.Sus / 2018 / PN.Jpa regarding a criminal case of Vehicle negligence which caused the death of another person committed by the Defendant in this case named RK on Saturday 28 April 2018 at around 20.30 WIB or at least at any other time other than that time in 2018 located near Pak Bastro's chicken noodles / Medicine Store of Langon or Ngabul-Matingan Vil. Langon Dist. Tahunan Reg. Jepara or at least in other places that are still included in the jurisdiction of the Jepara District Court has driving a Vehicle which due to his negligence resulted in a Traffic Accident, which resulted in the death of another person, the act of the defendant was carried out in the following ways:

That on Saturday, April 28, 2018 at around 20:15 WIB the defendant came home from work from the Kanal Pharmacy by riding a Honda Beat Police No. K-5 *** - ANC motorcycle, then the defendant would pick up the defendant's child who was at Vil. Langon Dist. Tahunan Reg. Jepara. Arriving at St. Ngabul-Mantingan Vil. Langon Dist. Tahunan Jepara, which at that time was paved, flat but the road was a bit dark because the lighting was far away and the weather was sunny, suddenly the Defendant saw the victim Suyatmi with a distance of \pm 15 (fifteen) meters, seeing this, the defendant was nervous / shocked. Tried to slam the motorcycle handlebar to the left, but because the distance was too close, the right handlebar touched the right hand of the victim Suyatmi, ${ }^{8}$

Seeing this incident, witness Agus Kisworo, who was at the scene of the incident with a distance of \pm 7 meters, immediately helped the victim Suyatmi, who was the wife of witness Agus Kisworo and saw the condition of the victim Suyatmi, at that time the left ear was bleeding then the victim Suyatmi was taken to RSU Kartini and after Visum was done et Repertum No. 416/05 / VI / 2018 dated 28 June 2018 which was made and signed by Dr. Califah Norsanti (Functional Medical staff doctor at RA Kartini Jepara Hospital) and was treated in the ICU room, the patient's condition worsened and died, the cause of death of the victim was not can be determined without an internal examination. ${ }^{9}$

The case of the Vehicle negligence criminal case which caused the death of another person with Number 186 / Pid.Sus / 2018 / PN.Jpa committed by the defendant RK by the public prosecutor was charged in the form of a cumulative indictment. The indictment of the Public Prosecutor is as follows;

- FIRST: Punishable in Article 310 paragraph (4) of Law of the Republic of Indonesia Number 22 of 2009 concerning Road Traffic and Transportation; Defendant RK on Saturday 28 April 2018 at around 20.30 WIB or at least at another time other than that time in 2018 was located near Pak Bastro's chicken noodles / Apotik Langon or Ngabul-Matingan Vil. Langon Dist. Tahunan. Jepara or at least in another place that is still included in the jurisdiction of the Jepara District Court has driven a Motorized Vehicle

\footnotetext{
${ }^{8}$ Excerpt Number Verdict No. 186/Pid.Sus/2018/PN.Jpa

${ }^{9}$ Ibid.
} 
which due to its negligence has resulted in a Traffic Accident, which resulted in the death of other people.

- SECOND: Punishable in Article 310 paragraph (3) of Law of the Republic of Indonesia Number 22 of 2009 concerning Road Traffic and Transportation; Defendant RK on Saturday 28 April 2018 at around 20.30 WIB or at least at another time other than that time in 2018 was located near Pak Bastro's chicken noodles / Apotik Langon or Ngabul-Matingan Vil.Langon Dist. Tahunan Reg. Jepara or at least in other places that are still included in the jurisdiction of the Jepara District Court has driven a Vehicle which due to its negligence has resulted in a Traffic Accident, resulting in the death of another person. ${ }^{10}$

In the case decision Number 186 / Pid.Sus / 2018 / PN.Jpa, the judge mentioned and imposed sanctions in the form of:

a. Stated that the Defendant RK was legally and convincingly proven guilty of committing the crime of "driving a motorized vehicle which due to his negligence resulted in a traffic accident which resulted in the death of other people".

b. To impose a sentence on the Defendant by means of a prison sentence of (4) four months;

c. To determine that the entire detention period the Defendant has served is deducted from the sentence imposed;

d. Ordered the Defendant to remain in detention Jail;

e. Determine evidence in the form of: 1 (one) unit SPM Honda Beat Police No. K-5 *** - ANC, 1 (one) sheet of STNK Honda Beat motorcycle Police No. K-5 *** ANC an RK address Vil. Langon RT ${ }^{* *} \mathrm{RW}^{* *}$ Dist. Tahunan Reg. Jepara / type: Honda / D1B02N26L2 A / T type: motorcycle in 2018, cylinder fill 180 cc, Noka. MHJFZ124JK341179, Nosin. JFZ1E2345110 white, TNKB color: Black STNK No.: 09083477 A valid until 02-03-2020; Returned to RK;

f. Charge the court fee to the Defendant of IDR 5,000.00 (five thousand rupiah). ${ }^{11}$

In this verdict, the judge decided based on the indictment of the public prosecutor on a cumulative charge, namely violating Article 310 paragraph (4) or both Article 310 paragraph (3) of Act No. 22 of 2009 concerning Road Traffic and Transportation. In considering a cumulative indictment, the judge considers the elements of the first indictment. ${ }^{12}$ In the case of the case Number 186 / Pid.Sus / 2018 / PN.Jpa, the judge found the criminal elements inherent in the first indictment, namely Article 310 paragraph (4) in which the elements are:

a. The "everyone" element;

b. The element of "driving a motorized vehicle which due to negligence has resulted in a traffic accident resulting in the death of other people". ${ }^{13}$

\footnotetext{
10 Ibid.

11 Ibid.

12 Interview with Yuli Purnomosidi, SH., MH, Judge at the Jepara District Court, Held on July 72020 at $11.00 \mathrm{WIB}$

13 Op.Cit.
} 
In the analysis of case Number 186 / Pid.Sus / 2018 / PN.Jpa, from the point of view of a judge, Yuli Purnomosidi, saw the judge in the case saw that seeing the legal facts that appeared in the trial, the element of negligence in the case not only purely from a Defendant RK as a driver but also the factor of the victim's negligence in crossing and the term incorrect timing when crossing saw that the speed of the vehicle and the speed of the human road were not the same. As for the inadequate traffic infrastructure factors such as unavailability of street lights, this is a big risk for motorized vehicle drivers in adjusting driving visibility. The element of negligence could not be totally attached to Defendant RK in the event of an accident. ${ }^{14}$

A burdensome subject: ${ }^{15}$

- The Defendant's actions caused the victim Suyatmi to die;

- The defendant did not have a driver's license as a standard condition for driving a motorized vehicle on the road.

Subject that relieve: ${ }^{16}$

- The defendant promised to be more careful in driving a motorized vehicle;

- The defendant's actions have been forgiven by the victim's family, Suyatmi;

- The defendant has never been convicted;

- The defendant still has a toddler.

In positive law, the Defendant RK positively violated the provisions in accordance with the aggravating matter, namely the accused's negligence which caused the death of another person and also the Defendant did not have a standardized driving license in the form of a driving license. As for the mitigating thing, the judge saw the defendant's personal side as a mother who still had children whose nutritional needs had to be fulfilled through the mother's breast milk and also with clarification of forgiveness from the victim's family in this case became a major momentum outside the scope of litigation in the sense of settlement. in a very necessary manner which also influences the judge's decision. Judges as an intermediary for someone to enter into punishment have their own conscientious views while still balancing positivistic elements to obtain justice. The conscience of judges is very necessary in making criminal decisions especially in the form of crimes in the form of negligence in which the legal subject has no incentive to commit a criminal act. ${ }^{17}$

The judge's decision should fulfill a sense of justice for all parties including for victims of crime, for criminals or among criminals. ${ }^{18}$ In juridically, no matter how heavy or light the punishment imposed by the judge will not be a problem as long as it does not exceed the minimum and maximum punishments threatened in the article concerned, but what matters is what was the basis or what was the reason for the judge's consideration in imposing the severity of the verdict in the

\footnotetext{
${ }^{14}$ Ibid.

${ }^{15}$ Op.Cit.

${ }^{16}$ Ibid.

${ }^{17}$ Op.Cit.

${ }_{18}$ Zainal Arifin Hoesein, 2013, Kekuasaan Kehakiman di Indonesia, Yogyakarta, Imperium , p. 52
} 
form of conviction. So that the decisions that are passed objectively can be accepted and fulfill a sense of justice. ${ }^{19}$

According to the author's analysis, the correct punishment theory for a criminal case of negligence that causes the death of another person in the area of traffic, it is necessary to emphasize the combined theory of punishment which explains that the imposition of punishment is grounded in two reasons, namely as a retaliation and as public order. Prioritizing retaliation, but the retaliation must not exceed the limit of what is necessary and sufficient for the public order to be maintained. A joint theory that prioritizes the protection of public order, but the suffering for the imposition of a sentence cannot be heavier than the actions committed by the convicted person. ${ }^{20}$

\section{Closing}

In positive law, the Defendant RK in case Number 186 / Pid.Sus / 2018 / PN.Jpa positively violated the provisions in accordance with the aggravating matter, namely the Accused's negligence causing the death of another person and also the Defendant did not have a standardized driving license in the form of a license Driving (SIM). As for the mitigating thing, the judge saw the defendant's personal side as a mother who still had children whose nutritional needs had to be fulfilled through the mother's breast milk and also with clarification of forgiveness from the victim's family in this case became a major momentum outside the scope of litigation in the sense of settlement. In a necessary manner which also influences the judge's decision. Judges as an intermediary for someone to enter into punishment have their own conscientious views while still balancing positivistic elements to obtain justice. The conscience of judges is indispensable in making criminal decisions, especially with crimes in the form of negligence in which the legal subject does not have the incentive to commit a criminal act.

The need for the obligation to present expert witnesses in obtaining legal certainty in any questionable examination at court cases of negligence which causes the death of another person in a traffic accident so that the essence of a conviction is handed down appropriately and fulfills a sense of justice for each party; Judges in imposing penalties must pay attention to criminal decisions not only as retaliation, but also to educate and improve behavior to return to society and the punishment fulfills a sense of justice for both the convict, the victim and the wider community; For legislators in the formation of the National Criminal Code and laws related to the crime of negligence in traffic, it seems that the crime

\footnotetext{
${ }^{19}$ Wilmar Ibni Rusydan, Umar Ma'ruf, dan Bambang Tri Bawono, Judicial Activism In Criminal Case To Ensure The Human Rights Upholding (Study In State Court Of Semarang), Jurnal Daulat Hukum, Vol.2 No.4, December 2019, url: http://jurnal.unissula.ac.id/index.php/RH/article/view/8347/3868

${ }^{20}$ Niniek Suparni, 2007, Eksistensi Pidana Denda Dalam Sistem Pidana dan Pemidanaan, Sinar Grafika, Jakarta, p. 19
} 
of accidents resulting in death must be given more attention, because it still requires scientific solutions.

\section{References}

Books

[1] Andi Hamzah, 2001, Bunga Rampai Hukum Pidana dan Acara Pidana, Ghalia Indonesia Jakarta

[2] Bambang Sunggono, 2010, Metodologi Penelitian Hukum, Rajawali Pers, Jakarta

[3] Kumpulan Kitab Undang-Undang Hukum, 2008, KUH Perdata, KUHP dan KUHAP, Wipres

[4] Niniek Suparni, 2007, Eksistensi Pidana Denda Dalam Sistem Pidana dan Pemidanaan, Sinar Grafika, Jakarta

[5] Zainal Arifin Hoesein, 2013, Kekuasaan Kehakiman di Indonesia, Yogyakarta, Imperium

Legislation

[1] Constitution of the Republic of Indonesia1945

[2] Criminal Code

[3] Act No. 48/2009 concerning Judicial Power

[4] Act No. 2 of 2009 concerning Road Traffic and Transportation

[5] Excerpt Number Verdict No. 186/Pid.Sus/2018/PN.Jpa

\section{Journal}

[1] Farhan Munirus Su'aidi, dan Abdullah Arief Cholil, Law Protection on Wife Whose The Claims Fall Due To Husband Refuse His Recompensation On Implementing Of Divorce Pledge, Jurnal Daulat Hukum, Vol.2 No.4, December 2019, url; http://jurnal.unissula.ac.id/index.php/RH/article/view/8367/3897

[2] Hengki Irawan, Sri Endah Wahyuningsih, dan Jawade Hafiz, Legal Protection For Victims Of Traffic Violations That Lead To Death (Case Study On Police Traffic of Rembang), Jurnal Daulat hukum, Vol.2 No.4, December 2019, url: http://jurnal.unissula.ac.id/index.php/RH/article/view/8349/3869

[3] Jamal Abdullah, Kepastian Hukum Terhadap Pelaku Tindak Pidana Delik Biasa yang diselesaikan dengan Mediasi (Studi Kasus Kecelakaan Lalu Lintas yang Menyebabkan Kematian), Jurnal Hukum, Vol.III No.1, February 2016, p. 8

[4] Anton Susanto, Ira Alia Maerani, and Maryanto, Legal Enforcement by the Police against Child of Criminal Doer of a Traffic Accident Who Caused Death (Case Study in Traffic Accident of Police Traffic Unit of Cirebon City Police Juridiction), Jurnal Daulat Hukum, Vol.3 No.1, March 2020, url: http://jurnal.unissula.ac.id/index.php/RH/article/view/8402/3928

[5] Wilmar Ibni Rusydan, Umar Ma'ruf, dan Bambang Tri Bawono, Judicial Activism In Criminal Case To Ensure The Human Rights Upholding (Study In 
State Court Of Semarang), Jurnal Daulat Hukum, Vol.2 No.4, December 2019, url: http://jurnal.unissula.ac.id/index.php/RH/article/view/8347/3868

\section{Interview:}

[1] Interview with Yuli Purnomosidi, SH., MH, Judge at the Jepara District Court, Held on July 72020 at 11.00 WIB 